${ }^{\circledR}$ Entomologica Fennica. 9 December 1999

\title{
Studies on the Heteroptera of the Khorasan province in N.E.Iran. II. Cimicomorpha: Miridae
}

\author{
Rauno E. Linnavuori \& Mehdi Modarres
}

Linnavuori, R. E. \& Modarres, M. 1999: Studies on the Heteroptera of the Khorasan province in N.E. Iran. II. Cimicomorpha: Miridae. — Entomol. Fennica 10: 215-231.

A list of the Miridae species of the Khorasan province in N.E. Iran is published. New synonymy: Orthotylus rudbaricus Linnavuori $1997=0$. turcmenorum Puchkov, 1976, syn.n.

Rauno E. Linnavuori, Saukkokuja 10, Somersoja, FIN-21220 Raisio, Finland Mehdi Modarres, College of Agriculture, Ferdowsi University, P.O. Box 917751163, Mashhad, Iran

Received 20 May, accepted 9 September 1999

\section{Introduction}

The present article is a continuation of Part I (Linnavuori \& Modarres 1998: 237-241). It is based on material collected by the senior author from April to July 1994 and May 1996 in Khorasan. The expeditions were made in cooperation with the College of Agriculture of the Ferdowsi University in Mashhad and the Plant Pests and Diseases Research Institute in Evin, Tehran.

\section{Material and methods}

Collecting trips were made to the areas mentioned in Part I. The material consisted of 159 species; 84 of them new for Iran. Nine new species were already described in Linnavuori $1995,1997 \mathrm{a}, 1997 \mathrm{~b}$, and 1998. A list of the findings is published below. For nomenclature and distributional data, the Catalogue of the Heteroptera of the Palaearctic Region III (Kerzhner \& Josifov 1999) was consulted.

The collected material is preserved in the Linnavuori collection, the College of Agriculture of the Ferdowsi University, Mashhad, and the Plant Pests and Diseases Research Institute in Evin, Tehran. The material was collected by Rauno Linnavuori, when no other collector is mentioned.

\section{Taxonomical notes}

Orthotylus (Parapachylops) putshkovi Josifov, 1974

Orthotylus putshkovi Josifov 1974: 91-92 Figs. 1 C-D, 2 A-I, 3 A-E.

Type material examined. Kirgisia: Ferganski chrebet, Kysyl-Unkür, 4 paratypes ( $\sigma^{*}$ o ), 4.IX.1972, Josifov, in coll. Linnavuori.

Discussion. There are slight differences in the male genitalia between the Iranian population and the type series: The dorsal angle of the sensory lobe of the left style is sharply triangular (rounded in the type series) and the subapical process of the median band of the vesica is somewhat dissimilar. But in lack of material between Middle Asia and Iran both populations are regarded as conspecific.

Orthotylus (Melanotrichus) eleagni Jakovlev, 1881, and O. (Melanotrichus) problematicus Linnavuori, 1953

Orthotylus eleagni Jakovlev, 1881: 200.

Orthotylus problematicus Linnavuori 1953: 107. 


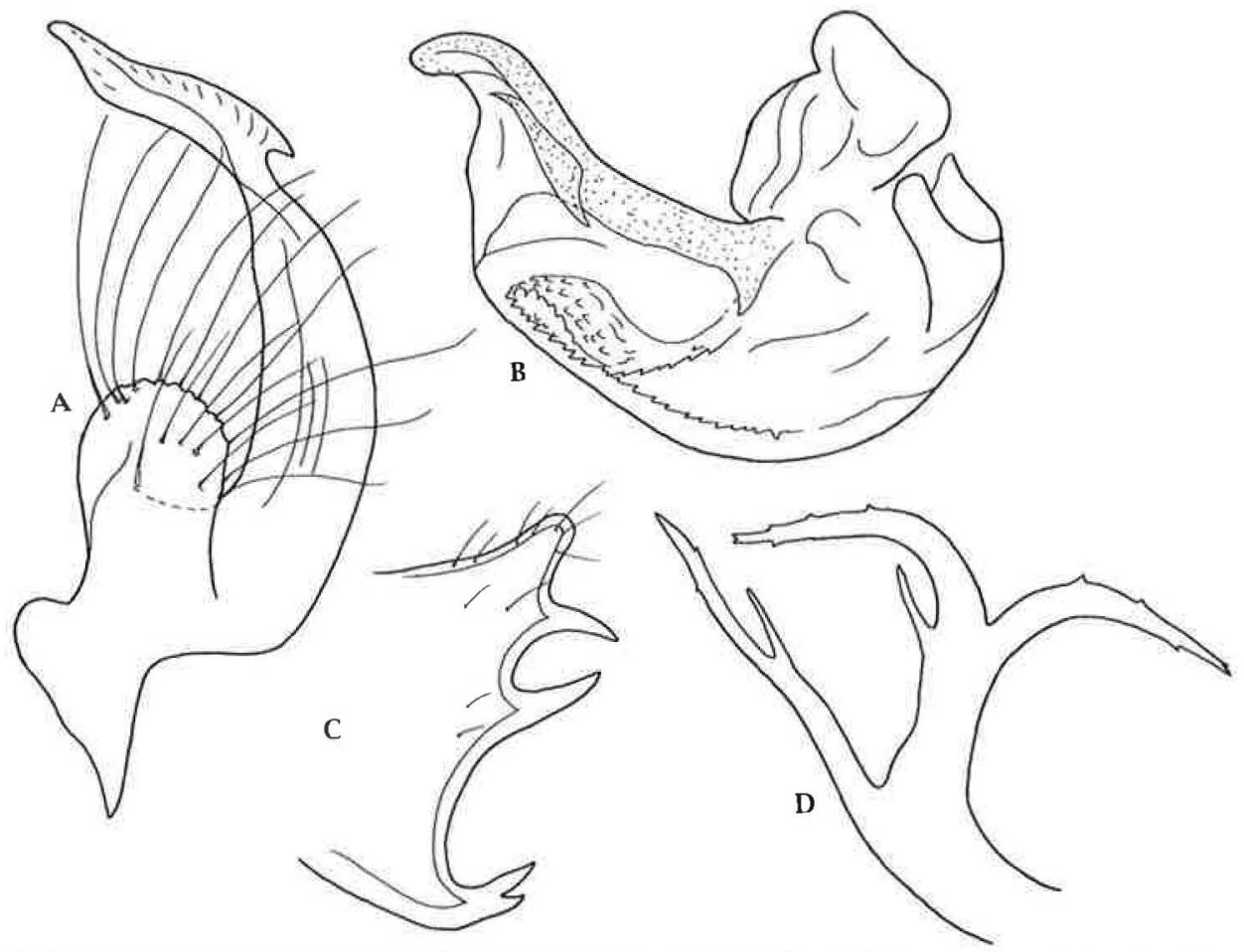

Fig.1. Dicyphus testaceus Reuter ( ex from Anbaran): A. left style; B. aedeagus in lateral view in slide mount. Orthotylus putshkovi Josifov (paratype); C. sensory lobe of left style; D. subapical process of vesica.

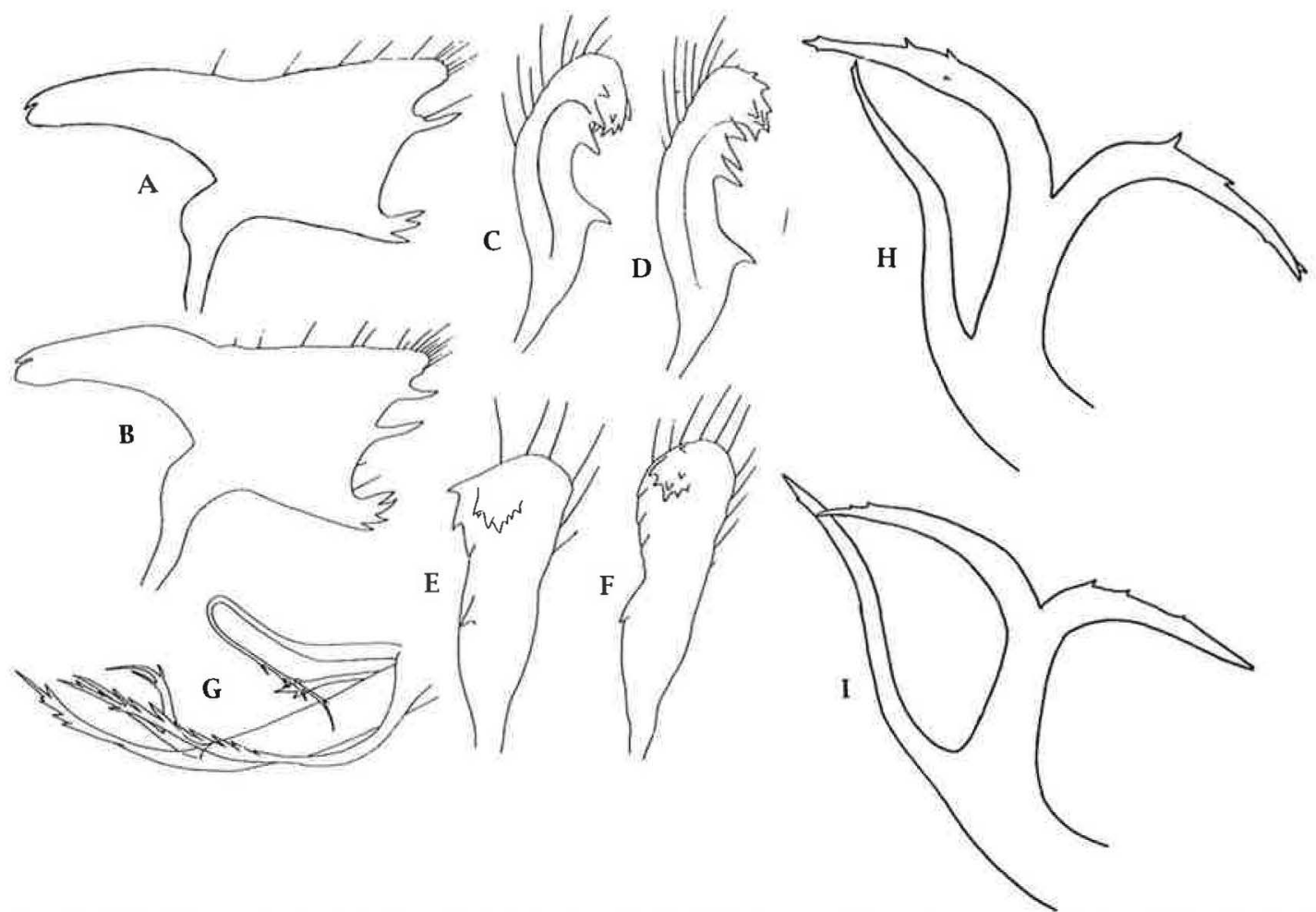

Fig. 2. Orthotylus putshkovi Josifov: A-B. left style; C-F. right style in different views; G. Vesica; H-I. subapical process of vesica ( exx from Zard and Evin, respectively). - A-G. after Josifov 1979. 




Fig. 3. Orthotylus putshkovi Josifov ( ex from Zard): A .process of pygofer; B. right style; C. left style; D. vesica; E. basal process by vesica.

Fig. 4 A-K.

Type material examined. Turkmenistan: Fl. Tschu, ơ holotype of $O$. problematicus, J.Sahlberg, in coll.Linnavuori.

Discussion. Both species are closely related, but can be distinguished by the following characters:

In $O$. eleagni the hair covering on the upper surface is shorter and pale, the antennae are more slender with the 1 st segment considerably shorter, 0.42-0.43 ( $\left.\sigma^{*}\right)$ or 0.38 ( () $\mathrm{x}$ as long as diatone, and the apical process of the right style being simple. In $O$. problematicus the hair covering on the upper surface is long and dark brown, the antennae are more incrassate with the 1 st segment $\left(\sigma^{\star}\right)$
$0.60 \mathrm{x}$ as long as diatone and the apical process of the right style is coarsely dentate.

Orthotylus (Melanotrichus) rudbaricus Linnavuori, 1997, = O. (Melanotrichus) turcmenorum Puchkov, 1976, syn.n.

Orthotylus (Melanotrichus) turcmenorum Puchkov 1976: 756.

Orthotylus (Melanotrichus) rudbaricus Linnavuori 1997 a: 307-309.

Type material of $O$. rudbaricus. Iran: Gilan, TutkabonRudbar, male holotype, 4 \% paratypes, 29.V-28.VI.1995; Manjil, o paratype, 16.V-14.VI.1995, Linnavuori, in coll. Linnavuori.

Discussion. O. rudbaricus was described from 


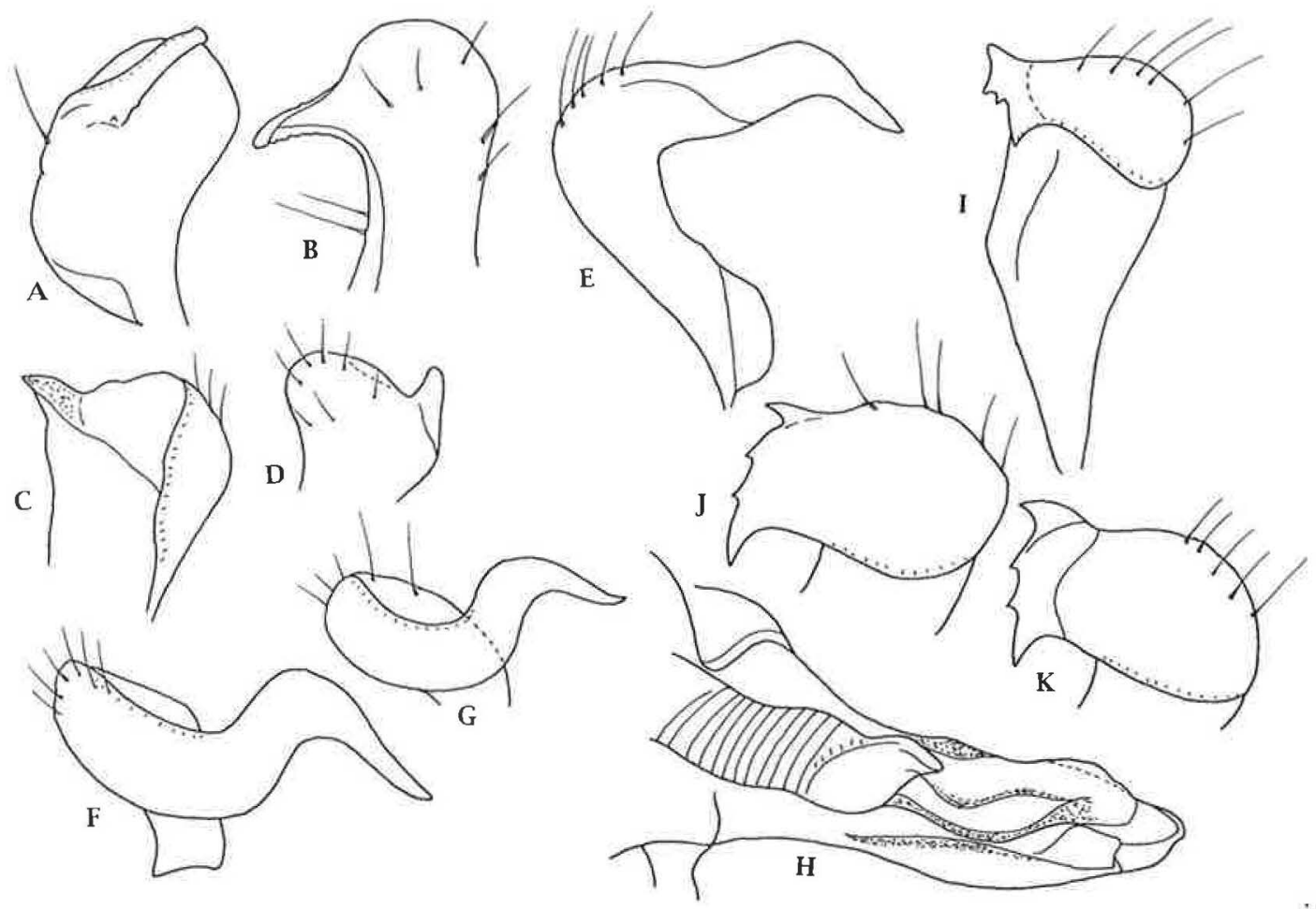

Fig. 4. Orthotylus eleagni Jakovlev: A-D. right style (ex from Kazakhstan, Nodeh, and two exx from Tabas, respectively); E-G. left style in different views (ex from Tabas); H. vesica. - O. problematicus Linnavuori (holotype); I-K. right style in different views.

an isolated area in Gilan on the basis of a robuster body, larger eyes in the male, somewhat shorter antennae, and broader right style. Examination of a large amount of material collected in 1996 from Parvand revealed numerous intermediates between $O$. rudbaricus and Middle Asia specimens of $O$. turcmenorum. Consequently both taxa are regarded as conspecific.

Hallodapus (Plagiorhamma) concolor Reuter, 1890, and H. (Plagiorhamma) pseudoconcolor Linnavuori, 1984

Plagiorhamma concolor Reuter 1890: 246.

Plagiorhamma pseudoconcolor Linnavuori 1984: 40.

Fig. 5 A-D.

Type material: $\boldsymbol{H}$. concolor: Turkmenistan: Bekljar-bek, $1 \sigma^{*}$ and 19 , J.Sahlberg, in the Zoological Museum of Helsinki University.

H. pseudoconcolor: Iraq: Dahuk, Sarsang, male holotype, several paratypes, 26-28.VIII. 1980; Ninawa, Al Qosh, several paratypes, 25. VIII.1980; Baghdad, several paratypes, IV-VI. 1980, Linnavuori. Holotype and paratypes in the
American Museum of Natural History, paratypes in coll. Linnavuori.
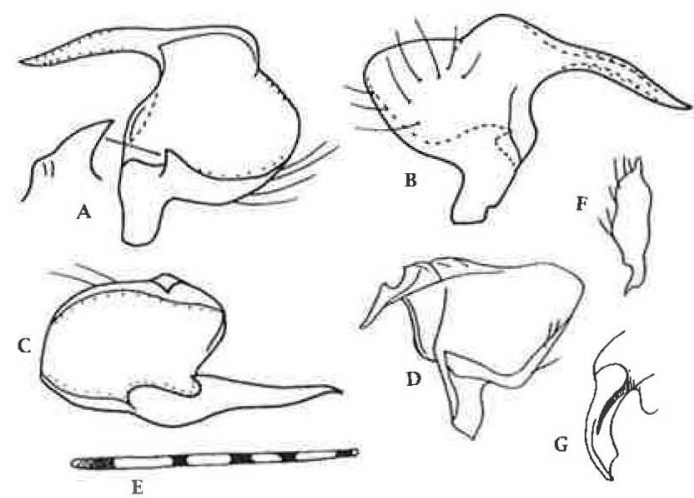

Fig. 5. Hallodapus pseudoconcolor Linnavuori: A-C. left style in different views. $-H$. concolor (Reuter); D. left style. - Camptotylus gracilis Wagner; E. 2nd antennal segment; F. right style; $G$. theca. - After Linnavuori 1975 and 1984 and Wagner 1957. 
Discussion. Both species are easily distinguished by the shape of the hypophysis of the left style, which in $H$. concolor is short and obliquely T-shaped, but in $H$. pseudoconcolor long and needle-like. Puchkov \& Puchkov (1983: 17-18) incorrectly recorded the latter species as $H$. concolor from Turkmenistan.

\section{List of species}

\section{Deraeocorinae \\ Deraeocorini}

Deraeocoris (Camptobrochis) punctulatus (Fallén, 1807). - Numerous exx. from Darreh Gaz, 14.VI.1994; $70 \mathrm{~km} \mathrm{~W}$ of Darreh Gaz, 14.VI.1994; Deh Shor 25 km N of Tabas, 17.IV.1994; Feyzabad, 16.V.1996; Khalkanlod $30 \mathrm{~km}$ E of Quchan, 7.VI.1994; Lotfabad, 15.VI.1994; Nodeh 30-40 km ESE of Bojnurd, 11.VII.1994; Mashhad, VVII.1994; Sabzevar, 31.V-1.VI.1994; Zaman Soofi $65 \mathrm{~km}$ W of Bojnurd, 12-13.VII.1994; Tabas, 1617.IV.1994. - Common in fields, steppes and hilly meadows. - Euro-Siberian.

Deraeocoris (Camptobrochis) serenus Douglas \& Scott, 1868. - Numerous exx. from $15 \mathrm{~km}$ E of Bojnurd, 15.VII.1994; Darreh Gaz, 15.VI. 1994; Golmakan $35 \mathrm{~km}$ NW of Mashhad, 10.V. 1994; Kashmar, 22-23.VI.1994; Khalkanlod 30 km E of Quchan, 7.VI.1994; Khargh 30 km SW of Quchan, 8-9.VI.1994; Lotfabad, 15.VI.1994; Nodeh $30 \mathrm{~km}$ ESE of Bojnurd, 11.VII.1994; Mashhad, V-VII.1994; Parvand $70 \mathrm{~km} \mathrm{~W}$ of Sabzevar, 4.VII.1994; Sabzevar, 14-15.V.1996; Tabas, 17.V.1996. - Common in gardens, steppes and hilly meadows. - Holomediterranean.

Deraeocoris (Knightocapsus) lutescens (Schilling, 1836). - Golestan Park $150 \mathrm{~km} \mathrm{~W}$ of Bojnurd, 1 ex, 14.VII.1994. — On Ulmus sp. Holomediterranean.

Deraeocoris (Phaeocapsus) pilipes Reuter, 1904. - Many exx. from Darreh Gaz, 15.VI. 1994; Feyzabad, 16.V.1996; Kashmar, 2223.VI.1994; Lotfabad, 15.VI.1994; Mashhad, VVII.1994; Parvand 70-80 km W of Sabzevar, 4.VII.1994; Sabzevar, 31.V-1.VI.1994. On Salix sp. - Irano-Turanian.

\section{Bryocorinae Dicyphini}

Macrolophus pygmaeus (Rambur, 1839) - Several exx. from Anbaran, 19.VII.1994; $15 \mathrm{~km} \mathrm{E} \mathrm{of}$ Bojnurd, 15.VII.1994; Darreh Gaz, 15.VI.1994; Golmakan 35 km NW of Mashhad, 10.V.1994; Khalcanlod $30 \mathrm{~km}$ E of Quchan, 7.VI.1994; Kashmar, 22-23.VI.1994; Mashhad, V-VII.1994; Nodeh 30-40 km ESE of Bojnurd, 12-13.VII.1994; Parvand 70-80 km W of Sabzevar, 31.V-1.VI. 1994; Sabzevar, 31.V-1.VI.1994; Sorond and Modar $70 \mathrm{~km}$ S of Tabas, 16.V.1994; Zaman Soofi $65 \mathrm{~km}$ W of Bojnurd, 12-13.VII.1994; Zoshk W of Shandiz, 24. V.1994. - On herbs such as Stach$y s$ in meadows. - Westpalaearctic.

Macrolophus melanotoma (A. Costa, 1853). — Kashmar, 1 ex, 22-23.VI.1994; Nodeh 30-40 km ESE of Bojnurd, 1 ex, 11.VII.1994.- On undergrowth in deciduous forests. - Holomediterranean. New for Iran.

Macrolophus epilobii Puchkov, 1978. - Golmakan $35 \mathrm{~km}$ NW of Mashhad, 4 exx., 10.V.1994. — On Epilobium hirsutum. - Previously known from Azerbaijan. New for Iran.

Dicyphus (Mesodicyphus) testaceus Reuter, 1879. — Left style and aedeagus in Fig.1 A-B. Anbaran $30 \mathrm{~km} \mathrm{~W}$ of Mashhad, several exx., 19.VII.1994. - On Mentha sp. in a river valley. - Known from Turkmenistan. New for Iran.

\section{Mirinae \\ Stenodemini}

Leptopterna inopinata Vinokurov, 1982. - $70 \mathrm{~km}$ W of Darreh Dasht, 1 ex, 14.VI.1994. — In a mountain meadow. - Known from Transcaucasia. New for Iran.

Teratocoris antennatus (Boheman, 1852). Nodeh 30-40 km ESE of Bojnurd, 1 ex, 11.VII. 1994. - Swept from Cyperus and Juncus in a moist meadow. - Holopalaearctic. New for Iran.

Stenodema (Brachystira) calcarata (Fallén, 1807). — $15 \mathrm{~km}$ E of Bojnurd, $1 \mathrm{ex}, 15$. VII.1994; Nodeh 30-40 km ESE of Bojnurd, 11.VII.1994; Tabas, 1 ex, 16-18.V.1994. - In meadows. Holopalaearctic. New for Iran.

Stenodema (Brachystira) pilosa (Jakovlev, 
1889). - Several exx. from Darreh Gaz, 15.VI. 1994; Lotfabad, 15.VI.1994; Nodeh 30-40 km ESE of Bojnurd, 11.VII.1994; Parvand $70 \mathrm{~km} \mathrm{~W}$ of Sabzevar, 4.VII.1994; Sabzevar, 31.V-1.VI. 1994. — In meadows. — Middle Asia. — New for Iran.

Stenodema (Stenodema) turanica Reuter, 1904. - Many exx. from $15 \mathrm{~km}$ E of Bojnurd, 15.VII.1994; Khargh $70 \mathrm{~km}$ SW of Quchan, 89.VI.1994; Nodeh 30-40 km ESE of Bojnurd, 11.VII.1994; Mashhad, V-VII.1994; Zaman Soofi $65 \mathrm{~km}$ W of Bojnurd, 12-13.VII.1994; Zoshk near Shandiz, 24.V.1994; Tabas, 16-18.V.1994. — In meadows. - Irano-Turanian.

Notostira poppiusi Reuter, 1911.-Many exx. from Anbaran $30 \mathrm{~km} \mathrm{~W}$ of Mashhad, 11.VII.1994; $70 \mathrm{~km}$ W of Darreh Gaz, 14.VI.1994; Khargh 70 km W of Quchan, 8-9.VI.1994; Nodeh 30-40 km ESE of Bojnurd, 11.VII.1994; Zoshk near Shandiz, 24.V.1994. - In hilly meadows. - IranoTuranian.

Megaloceroea recticornis (Geoffroy, 1785). Golestan Park $150 \mathrm{~km}$ W of Bojnurd, several exx., 14.VII.1994. - On undergrowth in deciduous forests. - Holarctic. New for Iran.

Trigonotylus caelestialium (Kirkaldy, 1902). — Lotfabad, 1 ex, 15.VI.1994; Feyzabad, 1 ex, 16.V.1996. — On grasses in meadows. — EuroSiberian.

Trigonotylus pulchellus (Hahn, 1834). - Several exx. from $15 \mathrm{~km}$ E of Bojnurd, 15.VII.1994; Darreh Gaz, 15.VI.1994; Khargh $70 \mathrm{~km} \mathrm{SW}$ of Quchan, 8-9.VI.1994; Lake Bazangan 50 km W of Sarakhs, 30.VI.1994; Lotfabad, 15.VI.1994; Mashhad, V-VII.1994; Nodeh 30-40 km ESE of Bojnurd, 11.VII.1994. — On grasses in meadows. - Westpalaearctic.

Trigonotylus tenuis Reuter, 1893. - $15 \mathrm{~km} \mathrm{E}$ of Bojnurd, 1 ex, 15.II.1994; Deh Shor 25 km N of Tabas, 1 ex, 17.IV.1994; Tabas, 1 ex, 14-15.V. 1994. - On grasses in meadows. - Cosmopolitan in warm regions. New for Iran.

\section{Mirini}

Phytocoris (Exophytocoris) scitulus Reuter, 1907. - Golmakan Park $150 \mathrm{~km}$ W of Bojnurd, $1 \mathrm{ex}$, 14.VII.1994. — On Cupressus. — Pontomediter- ranean. New for Iran.

Phytocoris (Eckerleinius) crito Linnavuori, 1972. - Deh Shor $20 \mathrm{~km} \mathrm{~N}$ of Tabas, $1 \mathrm{ex}, 17 . I V$. 1994. - On Artemisia sp. - Endemic for Iran.

Phytocoris (Eckerleinius) eileithyia Linnavuori, 1971. - Darreh Gaz, 1 ex, 15.VI.1994. Originally described from Armenia. New for Iran.

Phytocoris (Eckerleinius) transcaspicus Stichel, 1958. - Darreh Gaz, 1 ex, 15.VI.1994. - On Artemisia sp. — Known from Middle Asia. New for Iran.

Phytocoris (Eckerleinius) undulatus Reuter, 1877. - Deh Shor $20 \mathrm{~km} \mathrm{~N}$ of Tabas, 1 ex, 17.IV. 1994; near Parvand 70-80 km W of Sabzevar, many exx., 31.V-1.VI.1994, 14-15.V.1996. - On Haloxylon sp. - Irano-Turanian.

Creontiades pallidus (Rambur, 1845). - Several exx. from Deh Shor $25 \mathrm{~km} \mathrm{~N}$ of Tabas, 17. IV.1994; Kashmar, 22-23.VI.1994; Sabzevar, 31.V-1.VI.1994; near Tabas, 14-18.V.1994. — In fields and steppes. An important pest on cotton in Khorasan (a personal communication from Mr.S.M.Hosseini, Agricultural Research Center in Mashhad). - Holomediterranean, widely distributed in the Middle East and the Ethiopian Region.

Megacoelum brevirostre Reuter, 1879. Many exx. from Feyzabad, 16.V.1996; Kashmar, 22-23.VI.1994; Lotfabad, 15.VI.1994; near Parvand 70-80 km W os Sabzevar, 31.V-1.VI. 1994; Sabzevar, 3.VII.1994. - On plants in steppe and desert habitats.- Irano-Turanian, extending from Cyprus to Turkmenistan.

Adelphocoris lineolatus (Goeze, 1778). Numerous exx. from $15 \mathrm{~km}$ E of Bojnurd, 15.VII. 1994; Darreh Gaz, 15.VI.1994; Feyzabad, 16.V. 1996; Golestan Park 150 km W of Bojnurd, 14. VII.1994; Kashmar, 22-23.VI.1994; Khalkanlod $30 \mathrm{~km}$ E of Quchan, 7.VI.1994; Khargh $70 \mathrm{~km}$ SW of Quchan, 8-9.VI.1994; Lotfabad, 15.VI. 1994; Lake Bazangan, 30.VI.1994; Mashhad, VVII.1994; Nodeh 30-40 km ESE of Bojnurd, 11. VII.1994; Sabzevar, 31.V-1.VI.1994; Sarakhs, 2930.IV.1994; Tabas, 14-15.V.1994. - Common in gardens, fields, steppes, and on undergrowth in deciduous forests. - Holopalaearctic.

Closterotomus costae Reuter, 1888. - Golestan Park $150 \mathrm{~km}$ W of Bojnurd, 3 exx., 14.VII. 1994. - On undergrowth in deciduous forests. - Syrio-Anatolian. New for Iran. 
Reuterista unicolor Rosenzweig, 1997. near Parvand 70-80 km W of Sabzevar, 2 exx., 14-15.V.1996. - Collected in light trap in a desert habitat. - Besides Khorasan known from Middle and Central Asia.

Eurystylus bellevoyei (Reuter, 1879). - Can Chiroc $50 \mathrm{~km} \mathrm{~S}$ of Tabas, 6 exx., 18.V.1996; Feyzabad, 2 exx., 16.V.1996. - In steppe habitats. - Eremian with a wide range within the Sudanese and Holomediterranean subregions.

Dichrooscytus persicus Josifov, 1974. - 70 km W of Darreh Gaz, several exx., 14.VI.1994. - On Juniperus excelsa. - Irano-Turanian.

Taylorilygus apicalis (Fieber, 1861). - Sorond and Modar $70 \mathrm{~km} \mathrm{~S}$ of Tabas, $1 \mathrm{ex}, 18 . \mathrm{V}$. 1996. - In a hilly steppe. - Cosmopolitan in tropical and subtropical regions.

Lygus rugulipennis Poppius, 1911. - Several exx. from Lake Bazangan, 30.VI.1994; Khalkanlod $30 \mathrm{~km}$ E of Quchan, 7.VI.1994; Lotfabad, 15.VI.1994; Nodeh 30-40 km ESE of Bojnurd, 11.VII.1994; Mashhad, V-VII.1994; Sarakhs, 2830.IV.1994; Zoshk near Shandiz, 24.V.1994. In fields and hilly meadows. A pest on wheat. Holopalaearctic.

Lygus pratensis pratensis (Linnaeus, 1758). - Golestan Park $150 \mathrm{~km} \mathrm{~W}$ of Bojnurd, 3 exx., 14.VII.1994. - On undergrowth in deciduous forests. - Holopalaearctic.

Lygus gemellatus gemellatus (HerrichSchaeffer, 1835). - Numerous exx. from Anbaran $30 \mathrm{~km} \mathrm{~W}$ of Mashhad, 11.VII.1994; $15 \mathrm{~km}$ E of Bojnurd, 15.VII.1994; Darreh Gaz, 15.VI.1994; 70 km W of Darreh Gaz, 14.VI.1994; Feyzabad, 16.V.1996; Golestan Park $150 \mathrm{~km}$ W of Bojnurd, 14.VII.1994; Kashmar, 22-23.VI.1994; Khalkanlod $30 \mathrm{~km}$ E of Quchan, 7.VI.1994; Khargh 75 km SW of Quchan, 8-9.VI.1994; Lake Bazangan $50 \mathrm{~km} \mathrm{~W}$ of Sarakhs, 30.VI.1994; Lotfabad, 15. VI.1994; Mashhad, V-VII.1994; Nodeh 30-40 km ESE of Bojnurd, 11.VII.1994; near Parvand 70$80 \mathrm{~km}$ W of Sabzevar, 31.V-1.VI.1994; Sabzevar, 31.V-1.VI.1994; Tabas, 16-18.V.1996; Zaman Soofi $65 \mathrm{~km}$ W of Bojnurd, 12-13.VII.1994; Zosk near Shandiz, 24.V.1994. — On Artemisia spp. in steppes and hilly meadows. - Holopalaearctic.

Orthops (Orthops) kalmi (Linnaeus, 1758). - Several exx. from Golestan Park $150 \mathrm{~km} \mathrm{~W}$ of Bojnurd, 14.VII.1994; Khargh $70 \mathrm{~km} \mathrm{SW}$ of
Quchan, 8-9.VI.1994; Lotfabad, 15.VI.1994; Mashhad, V-VII.1994; Nodeh 30-40 km ESE of Bojnurd, 11.VII.1994; Zaman Soofi $65 \mathrm{~km} \mathrm{~W}$ of Bojnurd, 12-13.VII.1994. - On undergrowth in deciduous forests and gardens. - Holopalaearctic.

Orthops (Orthops) frenatus (Horváth, 1894). - $70 \mathrm{~km}$ W of Darreh Gaz, 1 ex, 14.VI.1994; Khalkanlod 30 km E of Quchan, 1 ex, 7.VI.1994; Khargh $70 \mathrm{~km}$ SW of Quchan, 1 ex, 8-9.VI. 1994; Mashhad, 1 ex, V-VII.1994. - In mountain meadows. - Recorded from Armenia, Iran (Täbriz), Afghanistan, and Middle Asia.

Orthops (Montanorthops) pilosulus (Jakovlev,1877). - Several exx. from Chan Chiroc 50 $\mathrm{km} \mathrm{S}$ of Tabas, 17.V.1994; Deh Shor $25 \mathrm{~km} \mathrm{~N}$ of Tabas, 17.IV.1994; Parvand 70-80 km W of Sabzevar, 14-15.V.1996; Sorond and Modar 70 km S of Tabas, 18.V.1994; Tabas, 16-17.IV.1994. - On Pteropyrum aucheri in hilly steppes. Irano--Turanian.

Liocoris tripustulatus (Fabricius, 1781). Several exx. from Anbaran $30 \mathrm{~km}$ W of Mashhad, 11.VII.1994; Golestan Park $150 \mathrm{~km}$ W of Bojnurd, 14.VII.1994; Golmakan $35 \mathrm{~km} \mathrm{NW}$ of Mashhad, 10.V.1994; Nodeh 30-40 km ESE of Bojnurd, 11.VII.1994; Zoshk near Shandiz, 11.IV.1994. — On Urtica sp. in gardens and deciduous forests. - Euro-Siberian. New for Iran.

Charagochilus gyllenhali (Fallén, 1807). Many exx. from Anbaran $30 \mathrm{~km}$ W of Mashhad, 11.VII.1994; 70 km W of Darreh Gaz, 14.VI. 1994; Golestan Park 150 km W of Bojnurd, 14. VII.1994; Lotfabad, 15.VI.1994; Mashhad, V-VII. 1994; Nodeh 30-40 km ESE of Bojnurd, 11.VII. 1994. — On Galium spp. — Holopalaearctic. New for Iran.

Polymerus (Poeciloscytus) vulneratus (Panzer, 1806). - Darreh Gaz, 1 ex, 15.VI.1994; Lotfabad, 4 exx., 15.VI.1994; Mashhad, 1 ex, V-VII.1994, Sarakhs, 1 ex, 29-30.IV.1994.- On Chenopodiaceae plants. Holopalaearctic.

Polymerus (Poeciloscytus) cognatus (Fieber, 1858). - Nodeh 30-40 km ESE Bojnurd, 2 exx., 11.VII.1994; Parvand 70-80 km W of Sabzevar, 1 ex, 4.VII.1994. - On Chenopodiaceae plants. -Holopalaearctic. New for Iran.

Polymerus (Poeciloscytus) brevicornis Reuter, 1878. - Several exx. from Golestan Park $150 \mathrm{~km}$ 
W of Bojnurd, 14.VII.1994; Lotfabad, 15.VI. 1994; Mashhad, V-VII.1994. - On Galium spp.-Widely distributed from Central and South Europe to Middle and Central Asia. New for Iran.

Polymerus (Poeciloscytus) lammesi Rinne, 1989. - $70 \mathrm{~km}$ W of Darreh Gaz, 3 exx., 14.VI. 1994. - On Galium sp. in a mountain slope. Distributed from southern Finland to Central Europe and the Balkan Peninsula. New for Iran.

Horistus turcomanus (Horváth, 1889). Zoshk near Shandix, 2 exx., 24.V.1994. - On Eremurus stenophyllus in a hilly meadow. - Syrio-Anatolian. New for Iran.

\section{Orthotylinae Halticini}

Myrmecophyes alacer Horváth, 1927. — 70 km W of Darreh Gaz, 3 exx., 14.VI.1994; Khargh 70 km W of Quchan, 1 ex, 8-9.VI.1994; Shourlough, several exx., 30.IV.1994. - In mountain meadows. - Also known from Caucasia and Transcaucasia.

Myrmecophyes variabilis Drapolyuk, 1989. — Khargh $70 \mathrm{~km}$ SW of Quchan, several exx., 89.VI.1994. - In mountain meadows. - Also known from Caucasia.

Orthocephalus modarresi Linnavuori, 1997. - $70 \mathrm{~km}$ W of Darreh Gaz, male holotype, female paratype, 14.VI.1994; Khargh 70 km SW of Quchan, female paratype, 8-9.VI.1994 in coll. Linnavuori. - In mountain meadows with Astragalus, Phlomis, Thymus, Verbascum, and Euphorbia. - Endemic for Iran.

Orthocephalus bivittatus Fieber, 1864. Several exx. from Roubat Sharaf $25 \mathrm{~km} \mathrm{SW}$ from Sarakhs, 30.IV.1994; Shourlogh 25 km W of Sarakhs, 30.IV.1994. - In hilly meadows with grasses, Apiaceae and Asteraceae such as Artemisia sp. - Northmediterranean. New for Iran.

Anapus kirschbaumi Stål, 1858. - Sarakhs, 1 ex, 8-9.VI.1994. - Swept from a steppe with Hordeum sp., Matricaria sp., Apiaceae, and halophytes. - Caspian, extending from Ukraine to Central Asia. New for Iran.

\section{Orthotylini}

Hyoidea notaticeps Reuter, 1876. - Shourlogh $25 \mathrm{~km} \mathrm{~W}$ of Sarakhs, 1 ex, 30.IV.1994. - On Ephedra sp.-Caspian, extending from Slovakia to Middle Asia. New for Iran.

Brachynotocoris puncticornis Reuter, 1880. — Numerous exx. from Darreh Gaz, 15.VI.1994; Lotfabad, 15.VI.1994; Mashhad, V-VII.1994. On Fraxinus rotundifolia. - Northmediterranean. New for Iran.

Reuteria kiritshenkoi Muminov, 1964. Golestan Park 150 km W of Bojnurd, 2 exx., 14. VII.1994. - On Ulmus sp. - Known from Caucasia. New for Iran.

Malacocoris chlorizans (Panzer, 1794) Anbaran, 7 exx., 19.VII.1994; Zaman Soofi, 1 ex, 12-13.VII.1994, 1 ex, 12-13.VII.1994. - On Fraxinus sp. - Westpalaearctic. New for Iran.

Pseudoloxops iranicus Kerzhner, 1962. Darreh Gaz, 1 ex, 15.VI.1994; Lotfabad, 2 exx., 15.VI.1994; Mashhad, 6 exx., V-VII.1994. — On Fraxinus sp. - Endemic for Iran.

Orthotylus (Orthotylus) prunicola Linnavuori, 1984. - Deh Shor $25 \mathrm{~km} \mathrm{~N}$ of Tabas, 5 exx., 17. IV.1994; Parvand $80 \mathrm{~km}$ W of Sarakhs, $1 \mathrm{ex}$, 14-15.V.1996. - On Amygdalus lycioides. Previously known from Iraq. New for Iran.

Orthotylus (Parapachylops) putshkovi Josifov, 1979. - Golmakan Park $150 \mathrm{~km}$ W of Bojnurd, 1 ex, 14.VII.1994; Zard $105 \mathrm{~km}$ WNW of Bojnurd, 7 exx., 13.VII.1994. - On Juniperus excelsa. - Known from Kirgizia. New for Iran.

Orthotylus (Melanotrichus) eleagni Jakovlev, 1881. - Many exx. from Darreh Gaz, 16.VI. 1994; Feyzabad, 16.V.1996; Kashmar, 22-23.VI. 1994; Khalkanlod $30 \mathrm{~km}$ E of Quchan, 7.VI.1994; Nodeh $40 \mathrm{~km}$ ESE of Bojnurd; 11.VII.1994; Parvand 70-80 km W of Sabzevar, 31.V-1.VI. 1994; Sabzevar, 31.V-1.VI.1994; Tabas, 1617.IV.1994. - On Elaegnus angustifolia. - Middle Asia. New for Iran.

Orthotylus (Melanotrichus) fieberi fieberi (Frey-Gessner, 1864). - Many exx. from Feyzabad, 16.V.1996; Nodeh $40 \mathrm{~km}$ ESE of Bojnurd, 11.VII.1994; Parvand 70-80 km W of Sabzevar, 12-15.V.1996; Shourlogh $35 \mathrm{~km}$ SW Sarakhs, 30.IV.1994. - On Chenopodium sp. - Pontomediterranean. 
Orthotylus (Melanotrichus) nymphias Linnavuori, 1974. - Feyzabad, several exx., 16.V.1996. - Collected in light trap. — Originally described from Turkmenistan. New for Iran.

Orthotylus (Melanotrichus) hirtulus Wagner, 1951. - Several exx. from Deh Shor $25 \mathrm{~km} \mathrm{~N}$ of Tabas, 17.IV.1994; Tabas, 15-17.IV.1994, 1618.V.1994. - On Anabasis in salt steppes. Eremian.

Orthotylus (Melanotrichus) flavosparsus (C.R. Sahlberg, 1841). - Many exx. from $15 \mathrm{~km}$ E of Bojnurd, 15.VII.1994; Darreh Gaz, 15.VI. 1994; Feyzabad, 16.V.1996; Lotfabad, 15.VI. 1994; Mashhad, V-VII.1994; Nodeh 30-40 km ESE of Bojnurd, 11.VII.1994; Sarakhs, 29-30.IV. 1994. - On Chenopodium sp. - Holarctic.

Orthotylus (Melanotrichus) viridissimus Linnavuori, 1961. - Lotfabad, several exx., 15.VI. 1994. — Collected in a light trap. — Previously known from Turkmenistan.

Orthotylus (Melanotrichus) turcmenorum Puchkov, 1967. - Near Parvand 70-80 km W of Sabzevar, numerous exx., 14-15.V.1996. — On Dendrostellera lesserti. - Irano-Turanian.

Orthotylus (Melanotrichus) pusillus Reuter, 1883. - Deh Shor $25 \mathrm{~km} \mathrm{~N}$ of Tabas, 3 exx., 17.IV. 1994; Tabas, 3 exx., 16-18.V.1994. - On Suaeda dendroides. - Eremian. New for Iran.

Orthotylus (Melanotrichus) minutus Jakovlev, 1877. - Many exx. from $15 \mathrm{~km}$ E of Bojnurd, 15.VII.1994; Lotfabad, 15.VI.1994; Mashhad, V-VII.1994; Nodeh 30-40 km ESE of Bojnurd, 11.VII.1994; Parvand 70-80 km W of Sabzevar, 4.VII.1994; Sabzevar, 31.V-1.VI.1994; Sarakhs, 29-30.IV.1994; Zaman Soofi $65 \mathrm{~km} \mathrm{~W}$ of Bojnurd, 12-13.VII.1994. - On Chenopodiaceae. - Pontomediterranean. New for Iran.

Orthotylus (Melanotrichus) rubidus (Puton, 1874). - Sarakhs, 2 exx., 29-30.IV.1994. - On Chenopodiaceae. - Holomediterranean. New for Iran.

Blepharidopterus diaphanus (Kirschbaum, 1856). - Anbaran, 1 ex, 19.VII.1994; Darreh Gaz, 1 ex, 15.VI.1994; Mashhad, 1 ex, V-VII. 1994; Nodeh 30-40 km ESE of Bojnurd, 6 exx., 11.VII.1994. — On Salix sp. — Euro-Siberian. New for Iran.

Cyrtorhinus caricis (Fallén, 1807). $-15 \mathrm{~km}$ E of Bojnurd, 1 ex, 15.VII.1994; Nodeh 30-40 km ESE of Bojnurd, several exx., 11.VII.1994; Zaman Soofi $65 \mathrm{~km}$ W of Bojnurd, 1 ex, 13.VII. 1994. - In moist meadows with Juncus sp. and Phragmites sp. - Holarctic. New for Iran.

\section{Phylinae \\ Pilophorini}

Pilophorus confusus (Kirschbaum, 1856). Anbaran, 5 exx., 11.VII.1994. — On Salix sp. Holopalaearctic. New for Iran.

\section{Hallodapini}

Alloeomimus kurdus Hoberlandt, 1953. - Several exx. from Darreh Gaz, 15.VI.1994; Lake Bazangan, 30.VI.1994; Nodeh 30-40 km ESE of Bojnurd; Sabzevar, 31.V-1.VI.1994. — Myrmecophilous. On Prosopis farcta together with Camponotus sp. - Also known from Iraq. New for Iran.

Hallodapus pseudoconcolor Linnavuori, 1984. - Feyzabad, 6 exx., 16.V.1996; Kashmar, 1 ex, 22-23.VI.1994; Lotfabad, 1 ex, 15.VI.1994. - In light trap. - Eremian, extending from Iraq to Turkmenistan. New for Iran.

Hallodapus suturalis (Herrich-Schaefer, 1839). Feyzabad, 7 exx., 16.V.1996; Lotfabad, 1 ex, 15.VI.1994; Mashhad, 4 exx., V-VII.1994; Sabzevar, 1 ex, 31.V-1.VI.1994. - In light trap. Northmediterranean, extending to Middle Asia. New for Iran.

Hallodapus costae (Reuter, 1890). - Several exx. from Deh Shor $25 \mathrm{~km} \mathrm{~N}$ of Tabas, 17. IV.1994; Tabas, 14-18.V.1994. — In light trap. - Eremian. New for Iran.

Laemocoris reuteri (Jakovlev, 1879). - Deh Shor $25 \mathrm{~km}$ N of Tabas, several exx., 15.V.1994; Lotfabad, 1 ex, 15.VI.1994; Tabas, 2 exx., 1618.V. 1994. - In light trap. - Irano-Turanian.

\section{Phylini}

Macrotylus (Alloeonycha) paykullii (Fallén, 1807). - Khargh $70 \mathrm{~km} \mathrm{SW}$ of Quchan, many exx., 8-9.VI.1994.- - In meadows on banks of a mountain brook. - Westpalaearctic. New for Iran. 
Nasocoris argyrotrichus Reuter, 1879. Numerous exx. from Darreh Gaz, 15.VI.1994; Golestan Park $150 \mathrm{~km}$ W of Bojnurd, 14.VI.1994; Zaman Soofi $65 \mathrm{~km}$ W of Bojnurd, 12-13.VII. 1994. - On Ephedra procera. - Irano-Turanian.

Nasocoris albipennis Lindberg, 1939. - Near Parvand 70-80 km W of Sabzevar, $1 \mathrm{ex}, 31$.V-1.VI. 1994. - On Ephedra sp. - Eremian, previously known from Egypt. New for Iran.

Boopidocoris nahidae Linnavuori, 1995. Near Parvand 70-80 km W of Sabzevar, $\&$ holotype, many paratypes (o $\circ$ ), 31.V-1.VI.1994, in coll. Linnavuori. - On Salsola richteri. - Endemic for Iran.

Plagiognathus bipunctatus Reuter 1883. Numerous exx. from $15 \mathrm{~km}$ E of Bojnurd, 16.VII. 1994; Darreh Gaz, 15.VI.1994; Feyzabad, 16.V. 1996; Khargh 70 km SW of Quchan, 5-6.VI.1994; Lotfabad, 15.VI.1994; Mashhad, V-VII.1994; Nodeh $30 \mathrm{~km}$ ESE of Bojnurd, 16.VII.1994; near Parvand, 70-80 km W of Sabzevar, 14-15.V.1996; Roubat Sharaf, 30.IV.1994; near Sabzevar, 31.V1.VI.1994; Sarakhs, 29-30.IV.1994; Shourlogh, 30.IV.1994. - In steppes and meadows. - Pontomediterranean.

Europiella decolor (Uhler, 1893). - Lotfabad, 1 ex, 15.VI.1994; near Parvand 70-80 km W of Sabzevar, 5 exx., 14-15.V.1996; Shourlogh, 1 ex, 30.IV.1994. - On Artemisia sp. Also collected in light traps. - Holarctic. New for Iran.

Atomoscelis onusta (Fieber, 1861). - Many exx. from $15 \mathrm{~km}$ E of Bojnurd, 15.VI.1994; Darreh Gaz, 15.VI.1994; Deh Shor $25 \mathrm{~km}$ N of Tabas, 17.IV.1994; Feyzabad, 16.V.1996; Lake Bazangan $50 \mathrm{~km} \mathrm{~W}$ of Sarakhs, 30.VI.1994; Lotfabad, 15.VI.1994; Mashhad, V-VII.1994; Nodeh $30 \mathrm{~km}$ ESE of Bojnurd, 11.VII.1994; near parvand 70-80 km W of Sabzevar, 4.VII.1994; near Sabzevar, 31.V-1.VI.1994; Zaman Soofi 65 km W of Bojnurd, 12-13.VII.1994. - On Atriplex sp. - Holomediterranean. New for Iran.

Badezorus ferdowsii Linnavuori, 1997. Mashhad, $q$ holotype and $7 \%$ paratypes, VVII.1994, in coll. Linnavuori. - On Fraxinus sp. Also collected in light trap in a garden. - Endemic for Iran.

Badezorus tomentosus (Reuter, 1904). - 15$20 \mathrm{~km} \mathrm{~N}$ of Tabas, $1 \mathrm{ex}, 14-15 . V .1994 .-\mathrm{On}$ halophytes in a salt steppe. - Eremian.

Badezorus immaculatus Linnavuori, 1997. Deh Shor $25 \mathrm{~km} \mathrm{~N}$ of Tabas, ơ holotype, 17.IV. 1994; Parvand 70-80 km W of Sabzevar, $2 \sigma^{\circ}$ and 4 p paratypes, 4.VII.1994, in coll. Linnavuori. Swept from desert vegetation. - Irano-Turanian.

Badezorus annulicornis (Reuter, 1879). Feyzabad, 3 exx., 16.V.1996. — In light trap. Irano-Turanian.

Camptozorus linnavuorii Kerzhner, 1996. Near Kashmar, o holotype, 22-23.VI.1994; near Parvand $70-80 \mathrm{~km} \mathrm{~W}$ of Sabzevar, क paratype, 31.V-1.VI.1994, in coll.Linnavuori. - Swept from desert vegetation. - Endemic.

Campylomma diversicorne Reuter, 1878. Many exx. from Chan Chiroc $50 \mathrm{~km}$ S of Tabas, 17.V.1994; Deh Shor $25 \mathrm{~km} \mathrm{~N}$ of Tabas, 18.IV. 1994; Feyzabad, 16.V.1996; Lotfabad, 15.VI. 1994; Mashhad, VI-VII.1994; near Parvand 70$80 \mathrm{~km} \mathrm{~W}$ of Sabzevar, 14-15.VI.1996; near Sabzevar, 31.V-1.VI.1994; Sarakhs, 29-30.IV. 1994; Tabas, 16-17.IV.1994. - In steppes on plants such as Artemisia sp. and Astragalus sp. Irano-Turanian.

Campylomma simillima Jakovlev, 1882. Vesica in Fig. 6 A. - Mashhad, 2 exx., V-VII. 1994. - In light trap. - Known from Middle Asia. - New for Iran.

Campylomma lindbergi Hoberlandt, 1952. Vesica in Fig. 6 B. — Sarakhs, 1 ex, 27.IV.1994. - On Pistacia vera. — Known from Cyprus, Iraq and Turkmenistan. New for Iran.

Campylomma nigronasuta Reuter, 1878. Vesica in Fig. 6 C. - Lotfabad, 1 ex, 15.VI.1994; near Parvand $70-80 \mathrm{~km}$ W of Sabzevar, 4.VII. 1994. — In light trap. — Irano-Turanian.

Campylomma verbasci (Meyer-Dür, 1843). - Many exx. from $15 \mathrm{~km}$ E of Bojnurd, 15.VII. 1994; Feyzabad, 16.V.1996; Khalkanlod 30 km E of Quchan, 7.VI.1994; Lotfabad, 15.VI.1994; Mashhad, V-VII.1994; Nodeh $40 \mathrm{~km}$ ESE of Bojnurd, 11.VII.1994; Tabas, 16-17.IV.1994; Zaman Soofi $65 \mathrm{~km}$ W of Bojnurd, 12-15.VII. 1994; Zard $100 \mathrm{~km}$ WNW of Bojnurd, 13.VII. 1994. - In steppes and mountain meadows on herbs such as Verbascum sp. Also found on Salix sp. - Holarctic.

Chlamydatus (Attus) eurotiae Kerzhner, 1962. 


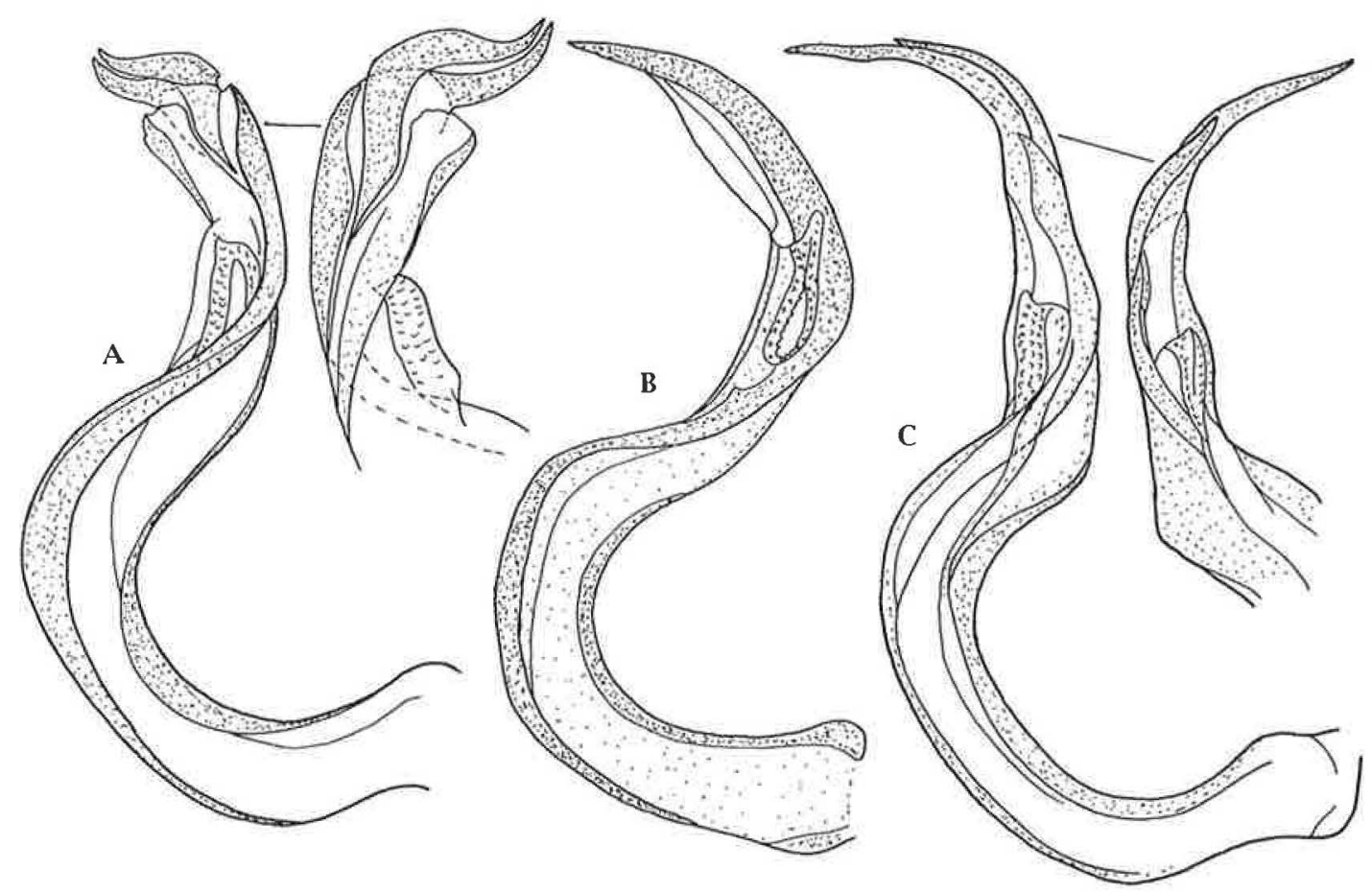

Fig. 6. Vesica of A. Campylomma simillima Jakovlev (ex from Mashhad); B. C. lindbergi Hoberlandt (ex from Badkhyeskii z-k, Turkmenistan); C. C. nigronasuta Reuter (ex from Lotfabad).

- Near Parvand $80 \mathrm{~km}$ W of Sahzevar, 1 ex, 1415.V.1996. - In light trap in a dune and steppe area. Originally found on Eurotia ceratoides in Kazakhhstan.

Sthenaropsis obscurus Poppius, 1912. Vesica in Fig. $7 \mathrm{~A}$, that of the related species $S$. schachrudicus Linnavuori, 1964 (Irano-Turanian) in Fig. 7 B-C. - Near Parvand 70-80 km W of Sabzevar, many exx., 31.V-1.VI.1994. - On Convolvulus erinaceus in dune habitats. Known from Middle Asia. New for Iran.

Sthenaropsis piperatus Linnavuori, 1964. Near Sabzevar, several exx., 31.V-1.VI.1994. On Lycium depressum. - Known from Middle Asia. New for Iran.

Compsidolon (Compsidolon) elegantulum Reuter, 1899. - $70 \mathrm{~km}$ W of Darreh Gaz, 2 exx., 14.VI.1994. - On Parietaria sp. in a steep mountain slope. - Syrio-Anatolian. New for Iran.

Compsidolon (Compsidolon) nebulosum (Reuter, 1878). — Many exx. from Anbaran 30 $\mathrm{km} \mathrm{W}$ of Mashhad, 19.VII.1994; $15 \mathrm{~km} \mathrm{E}$ of Bojnurd, 15.VII.1994; Lotfabad, 15.VI.1994;
Mashhad, V-VII.1994; Tabas, 16-18.V.1994. On undergrowth in gardens and deciduous forests. - Irano-Turanian.

Compsidolon (Apsinthophylus) pumilum (Jakovlev, 1876). - Numerous exx. from Deh Shor $25 \mathrm{~km}$ N of Tabas, 17.IV.1994; Parvand 70-80 km W of Sabzevar, 14-15.V.1996; Tabas, 16-17.IV and 16-18.V.1994. - On Artemisia sp. in steppes. - Pontomediterranean, extending to Middle and Central Asia. New for Iran.

Compsidolon (Apsinthophylus) bipunctatum eremita Puchkov, 1977. - Numerous exx. from Deh Shor $25 \mathrm{~km}$ N of Tabas, 14-15.V.1994; Parvand 70-80 km W of Sabzevar, 31.V-1.VI. 1994, 14-15.V.1996; Tabas, 14-15.V.1994. — On Artemisia sp. in steppes. - Irano-Turanian. New for Iran.

Lepidargyrus instabilis (Reuter, 1878). Feyzabad, 1 ex, 16.V.1996. - Collected in light trap. - Known from Middle Asia. New for Iran.

Oncotylus (Cylindromelus) setulosus (Herrich - Schaeffer, 1837). - Darreh Gaz, 4 exx., 15.VI. 1994; Golestan National Park 150 km W of Bo- 


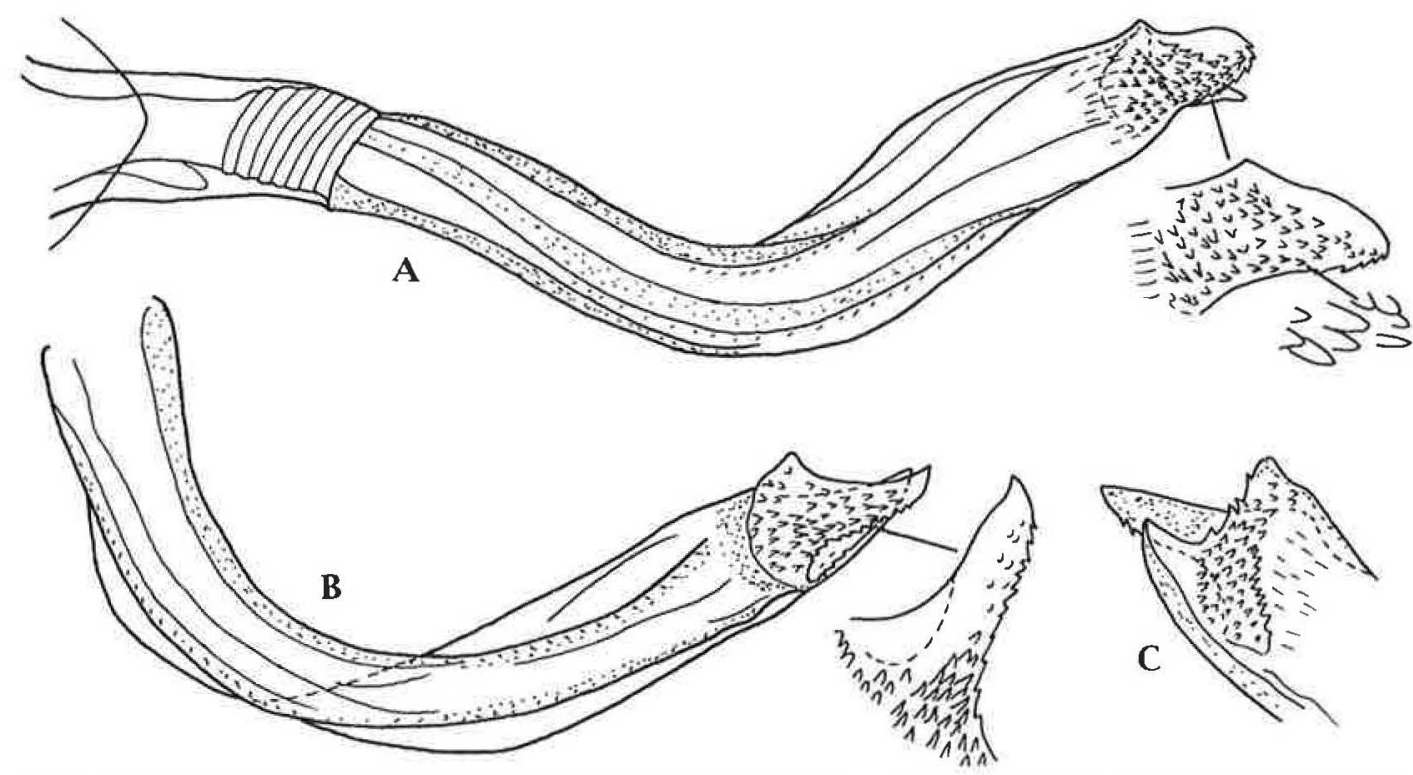

Fig. 7. Sthenaropsis obscurus Poppius (ex from Parvand): A. vesica. - S. schachrudicus Linnavuori (paratype); B. vesica; C. apex of vesica.

jnurd, 1 ex, 14.VII.1994; Mashhad, 1 ex, V-VII. 1994; Nodeh 30-40 km ESE of Bojnurd, 3 exx., 11.VII.1994. - On Centaurea sp. in steppes. Pontomediterranean, extending to Middle Asia. New for Iran.

Oncotylus (Oncotylus) vitticeps Reuter, 1879. -Several exx. from Feyzabad, 16.V.-1996; Khalcanlod $30 \mathrm{~km}$ E of Quchan, 7.VI.1994; Mashhad, V-VII.1994; Nodeh 30-40 km ESE of Bojnurd, 11.VII.1994. - On Asteraceae in mountain steppes. - Known from Middle Asia. New for Iran.

Oncotylus(Oncotylus) affinis Jakovlev, 1882. - Claw, styles, theca, and vesica in Fig. 8 A-F. - Sarakhs, 1 ex, 29-30.IV.1994. — In a hilly steppe. - Known from Middle Asia. New for Iran.

Tytthus parviceps (Reuter, 1890). - Deh Shor $25 \mathrm{~km} \mathrm{~N}$ of Tabas, 1 ex, 17.IV.1994; near Tabas, 1 ex, 14-15.V.1994. - On grasses in moist localities. - Intertropical. New for Iran.

Stirophylus aristidae Wagner, 1965. - Tabas, 4 우 ㅇ probably of this species, 16-18.V.1994. - On grasses in a steppe. - Eremian. New for Iran.
Amblytylus peitho Linnavuori, 1997. - Sarakhs, male holotype, $3 \sigma^{*}$ and 29 paratypes, 2930.IV.1994; Roubat Sharaf, \& paratype, 30.IV. 1994; Shourlogh $35 \mathrm{~km} \mathrm{SW}$ of Sarakhs, 2 \% paratypes, 30.IV.1994, in coll. Linnavuori. - On Hordeum sp. and other grasses in steppes. - Endemic for Iran.

Amblytylus concolor Jakovlev, 1877. - Numerous exx. from Roubat Sharaf, 30.IV.1994; Sarakhs, 29-30.IV.1994; Shourlogh $35 \mathrm{~km} \mathrm{SW}$ of Sarakhs, 30.IV.1994. - Together with the preceding species. - Pontomediterranean.

Megalocoleus molliculus (Fallén, 1807). Several exx. from Khalcanlod $30 \mathrm{~km}$ E of Quchan, 7.VI.1994; Khargh $70 \mathrm{~km}$ SW of Quchan, 8-9.VI. 1994. - On Asteraceae in hilly meadows. Holopalaearctic. New for Iran.

Pronototropis punctipennis (Fieber, 1864). Shourlogh $35 \mathrm{~km}$ SW of Sarakhs, 1 ex, 30.IV. 1994. - In a hilly meadow. - Caspian. New for Iran.

Pleuroxonotus nasutus Reuter, 1903. Parvand 70-80 km W of Sabzevar, 3 exx., 14-15.V. 1996. - In light trap in a dune area. - Formerly 


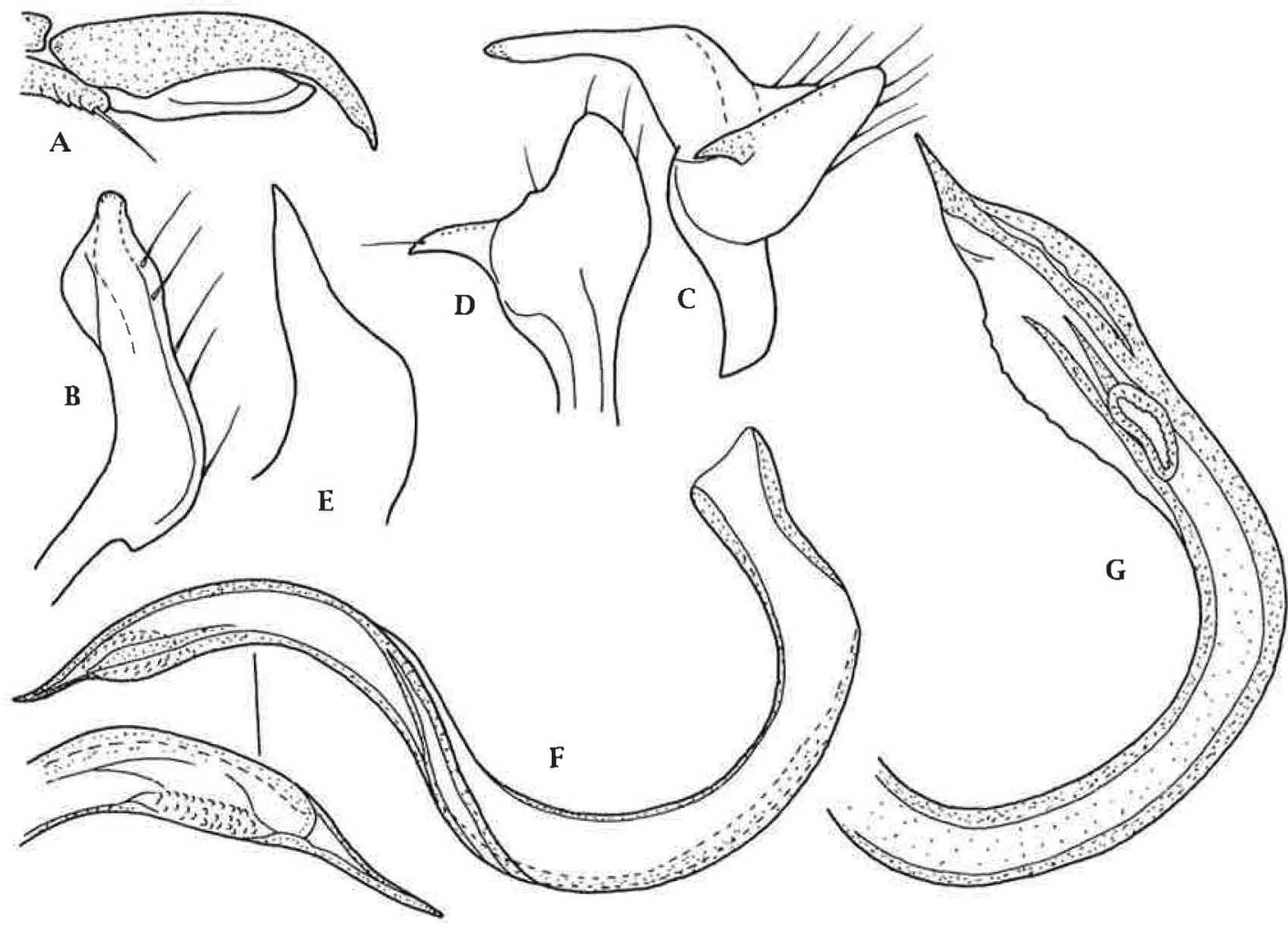

Fig. 8. Oncotylus affinis Jakovlev: A. claw; B. right style; C-D. left style; E. theca; F. vesica. - Conostethus cf. hungaricus Wagner; $\mathrm{G}$. vesica.

known from Turkmenistan. New for Iran.

Glaucopterum kareli Wagner, 1963. - Many exx. from Khalkanlod $30 \mathrm{~km}$ E of Quchan, 7.VI. 1994; Khargh $70 \mathrm{~km} \mathrm{SW}$ of Quchan, 8-9.VI.1994; Tabas, 16-17.IV.1994. - On Eleagnus angustifolia. - Irano-Turanian. New for Iran.

Glaucopterum deserticola (Wagner, 1952). - Parvand 70-80 km W of Sabzevar, 6 exx., 1415.V.1996. — On Haloxylon sp. — Eremian. New for Iran.

Glaucopterum pteropyri Linnavuori, 1998. Can Chiroc $50 \mathrm{~km}$ S of Tabas, o holotype, 1 \% paratype, 17.V.1994, $1 \sigma^{\circ}$ and 1 o paratype, 18.V. 1996; Sorond and Modar $70 \mathrm{~km} \mathrm{~S}$ of Tabas, 1 ㅇ paratype, 18.V.1994, in coll.Linnavuori, a paratype in Plant Pests and Diseases Research Institute, Tehran. - On Pteropyrum aucheri. - Endemic.

Conostethus cf. hungaricus Wagner, 1941. Vesica in Fig. 8 G. - Roubat Sharaf 25 km SW of Sarakhs, several exx., 30.IV.1994. - In a hilly meadow. - Pontomediterranean. New for Iran.

Monocris griseolus Puchkov, 1974. — Esfideh, 1 ex, 20.IV.1994; Parvand 70-80 km W of Sabzevar, several exx., 31.V-1.VI.1994, 1415.V.1996; Sabzevar, 1 ex, 31.V-1.VI.1994. On halophytes in sandy habitats. - Known from Middle Asia. New for Iran.

Leucopterum candidatum Reuter, 1879. Lake Bazangan $50 \mathrm{~km}$ W of Sarakhs, several exx., 30.VI.1994; Sarakhs, 1 ex, 29-30.IV.1994. — On Suaeda microphylla. - Caspian.

Voruchia vittigera Reuter, 1879. - Yazd: Ashkazar, 1 ex, 18-24.V.1996. - In light trap in a garden. - Known from Middle Asia. New for Iran.

Solenoxyphus punctipennis (Reuter, 1879).Many exx. from Darreh Gaz, 15.VI.1994; Feyzabad, 16.V.1996; Lotfabad, 15.VI.1994; Mashhad, V-VII.1994; Parvand 70-80 km W od Sabzevar, 4.VII.1994; Sabzevar, 31.V-1.VI.1994; Sarakhs, 29-30.IV.1994; Tabas, 14-15.V.1994; Zaman 
Soofi $65 \mathrm{~km}$ W of Bojnurd, 12-13.VII.1994. In steppes with grasses, Asteraceae and Astragalus sp. - Irano-Turanian.

Psallopsis haloxyli Puchkov, 1976, - Parvand $70-80 \mathrm{~km} \mathrm{~W}$ of Sabzevar, 5 exx., 31.V-1.VI and 4.VII.1994. - On Haloxylon aphyllum. Known from Middle Asia. New for Iran.

Psallopsis kirgisicus (Becker, 1864). Sabzevar, 2 exx., 31.V-1.VI.1994. - On halophytes such as Salsola sp. - Pontomediterranean extending to Middle Asia.

Psallopsis similis Wagner, 1958. -Many exx. from $15 \mathrm{~km}$ E of Bojnurd, 15.VII.1994; Feyzabad, 16.V.1996; Nodeh 30-40 km ESE of Bojnurd, 11.VII.1994; Parvand 70-80 km W of Sabzevar, 4.VII.1994; Sarakhs, 29-30.IV.1994. - On Suaeda sp. Eremian, extending from Saudi Arabia and Palestine to South Russia, Caucasia and Middle Asia.

Psallopsis kaliidicola Konstantinov, 1997. Lolfabad, 1 ex, 15.VI.1994; Sarakhs, 1 ex, 2930.IV.1994. - Recorded from Kalidium sp. in Middle and Central Asia. New for Iran.

Psallopsis caspia Konstantinov, 1997. Lotfabad, 3 exx., 15.VI.1994. - Recorded from Salsola laricina and Kochia? sp. - Caspian.

Psallopsis halostachydis Puchkov, 1976. Lotfabad, 3 exx., 15.VI.1994; Sabzevar, $1 \mathrm{ex}$, 31.V-1.VI.1994. - Recorded from Halostachys belangeriana. - Extending from Dagestan to Inner Mongolia. New for Iran.

Psallopsis bisulcis Linnavuori, 1961. Parvand 70-80 km W of Sabzevar, 8 exx., 31.V1.VI.1994; Sabzevar, 1 ex, 3.VII.1994. — On Aellenia subaphylla. - Eremian, extending from Palestine to Middle Asia.

Psallopsis basalis Reuter, 1904. - Numerous exx. from Deh Shor, $25 \mathrm{~km} \mathrm{~N}$ of Tabas, 17.IV and 16.V.1994; Kahe 30-60 km W of Kashmar, 21-22.VI.1994; Parvand 70-80 km W of Sabzevar, 31.V-1.VI.1994; Sabzevar, 31.V-1.VI and 3.VII. 1994; Sorond and Modar $70 \mathrm{~km}$ S of Tabas, 18.V.1 994, Tabas, 16-18.V.1994. - On Seidlitzia rosmarinus. - Eremian, extending from Saudi Arabia and Palestine to Iraq and Iran.

Atomophora pentheus Linnavuori, 1971.Many exx. from Chan Chiroc $50 \mathrm{~km} \mathrm{~S}$ of Tabas, 17.V.1994; Parvand 70-80 km W of Sabzevar, 31.V-1.VI and 4.VII.1994, 14-15.V.1996. - On
Calligonum. - Endemic for Iran.

Atomophora atripes Linnavuori, 1997. Parvand 70-80 km W of Sabzevar, $\sigma^{7}$ holotype, $2 \sigma^{*}$ and $4 \circ$ paratypes, 31.V-1.VI.1994, in coll. Linnavuori, numerous exx. 14-15.V.1996. - On Calligonum sp. in dunes. - Endemic for Iran.

Atomophora maculosa maculosa Reuter, 1903. - Parvand 70-80 km W of Sabzevar, several exx., 14-15.V.1996. — On Calligonum sp. - Known from Middle Asia. New for Iran.

Atomophora astraia Linnavuori, 1997. Tabas, ơ holotype, 1 o paratype, 16-18.V.1994, in coll. Linnavuori. - Collected in light trap in a salt marsh. The main vegetation consisted of $\mathrm{Cal}$ ligonum sp., Haloxylon persicum and Suaeda dendroides. - Endemic.

Camptotylidea lineata (Reuter, 1901). Parvand 70-80 km W of Sabzevar, 6 exx., 1415.V.1996. - At lamp in a dune area. - Recorded from Tournefortia sogdiana and Heliotropium sp. in Middle Asia. New for Iran.

Camptotylidea albovittata (Reuter, 1903). Parvand 70-80 km W of Sabzevar, numerous exx., 14-15.V.1996. — On Astragalus sp. — Known from Middle Asia. New for Iran.

Camptotylidea flavescens (Puchkov, 1976). - Numerous exx. from Kahe $35-60 \mathrm{~km} \mathrm{~W}$ of Kashmar, 21-22.VI.1994; Kashmar, 22-23.VI. 1994; Parvand 70-80 km W of Sabzevar, 31.V1.VI .1994 and 14-15.V.1996; Sabzevar, 31.V1.VI.1994. - On Haloxylon aphyllum. — Known Turkmenistan. New for Iran.

Camptotylidea suturalis (Reuter, 1903). Numerous exx. from Deh Shor $25 \mathrm{~km} \mathrm{~N}$ of Tabas, 17.IV.1994; Kashmar, 22-23.VI.1994; Parvand 70-80 km W of Sabzevar, 31.V1.VI.1994, 14-15. V.1996; Sabzevar, 3.VII.1994; Sarakhs, 29-30.IV. 1994; Tabas, 16-18.V.1994. On Haloxylon sp. - Irano-Turanian.

Camptotylidea persica Wagner, 1957. Parvand 70-80 km W of Sabzevar, 4 exx., 14-15. V.1996. - In light trap in a dune area. - Endemic for Iran.

Maurodactylus albidus (Kolenati, 1845). Shourlogh $35 \mathrm{~km}$ SW of Sarakhs, 6 exx., 30.IV. 1994. - In a hilly steppe. - Holomediterranean, extending to Middle Asia.

Maurodactylus nigrigenis (Reuter, 1890). Feyzabad, 2 exx., 16.V.1996; Mashhad, 1 ex, V- 
VII.1994. - On Artemisia sp. in steppes. - Eremian, extending from North Africa to Central Asia. New for Iran.

Auchenocrepis reuteri Jakovlev, 1876. Golestan National Park $150 \mathrm{~km}$ W of Bojnurd, 1 ex, 14.VII.1994. - On Tamarix sp. — Pontomediterranean.

Auchenocrepis alboscutellata Puton, 1874. - Many exx. from $15 \mathrm{~km}$ E of Bojnurd, 15.VII. 1994; Darreh Gaz, 15.VI.1994; Deh Shor 25 km N of Tabas, 16.V.1994; Lotfabad, 15.VI.1994; Parvand 70-80 km W of Sabze-var, 4.VII.1994; Shams Abad 30 km SE of Kashmar, 23.VI.1994; Tabas, 16-17.IV and 14-15.V. 1994. — On Tamarix sp. - Eremian, extending from North Africa to Iran.

Voruchiella pallida (Reuter, 1878). Parvand $70-80 \mathrm{~km} \mathrm{~W}$ of Sabzevar, numerous exx., 14-15.V.1996. - On Haloxylon sp. and Calligonum sp. - Known from Middle Asia. New for Iran.

Voruchiella plagiata Poppius, 1912. - Claw and male genitalia in Fig. 9 A-E. - Tabas, several exx., 16-17.IV.1994. - On Haloxylon aphyllum. - Known from Middle Asia. New for Iran.

Voruchiella haloxyli Puchkov, 1984. - Many exx. from Deh Shor $25 \mathrm{~km} \mathrm{~N}$ of Tabas, 17.IV.1994; Esfideh, 20.IV.1994; Parvand 70-80 km W of Sabzevar, 14-15.V.1996; Tabas, 16-17.IV.1994. -

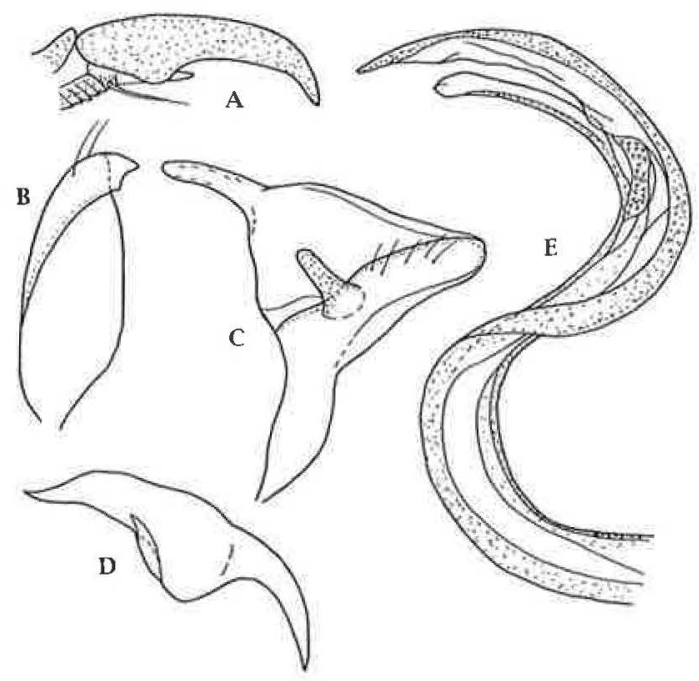

Fig. 9. Voruchiella plagiata Poppius (ex from Tabas): A. claw; B. right style; C. left style; D. theca; E. vesica.
On Haloxylon persicum. - Known from Middle Asia. New for Iran.

Voruchiella tincta (Jakovlev, 1903). Parvand 70-80 km W of Sabzevar, 14-15.V.1996. — On Calligonum sp. - Irano-Turanian.

Tuponia (Tuponia) persica Wagner, 1957. Several exx. from Deh Shor $25 \mathrm{~km} \mathrm{~N}$ of Tabas, 16-17.IV and 16.V.1994; Lake Bazangan $50 \mathrm{~km}$ W of Sarakhs, 30.VI.1994; Lotfabad, 15.VI.1994; Parvand $70-80 \mathrm{~km}$ W of Sabzevar, 31.V-1.VI. 1994; Tabas, 14-15.V.1994, 17.V.1996. — On Tamarix sp. - Eremian, extending from Yemen and Saudi Arabia to Middle Asia.

Tuponia (Tuponia) mixticolor (A. Costa, 1862). - Many exx. from Deh Shor $25 \mathrm{~km} \mathrm{~N}$ of Tabas, 17.IV.1994; Feyzabad, 16.V.1996; Lake Bazangan, 30.VI.1994; Tabas, 14-15.V.1994. On Tamarix sp. - Holomediterranean.

Tuponia (Tuponia) ninlil Linnavuori, 1984. - Deh Shor $25 \mathrm{~km} \mathrm{~N}$ of Tabas, 1 ex, 17.IV.1994; Tabas, 4 exx., 16-17.IV.1994. — On Tamarix sp. - Previously known from Iraq. New for Iran.

Tuponia (Tuponia) algirica Wagner, 1965. Sarakhs, 1 ex, 29-30.IV.1994. - On Tamarix sp. - Eremian, extending from North Africa to Iran. New for Iran.

Tuponia (Tuponia) ayasensis Wagner, 1963. - Many exx. from Lake Bazangan $50 \mathrm{~km} \mathrm{~W}$ of Sarakhs, 30.VI.1994; Lotfabad, 15.VI.1994; Mashhad, VI-VII.1994; Sarakhs, 26-30.IV.1994. - On Tamarix sp. - Syrio-Anatolian. New for Iran.

Tuponia (Tuponia) dehshorana Linnavuori, 1997. - Deh Shor $25 \mathrm{~km} \mathrm{~N}$ of Tabas, o holotype, 16.V.1994; Darreh Gaz, $3 \sigma^{*}$ and 13 \% paratypes, 15.VI.1994, in coll. Linnavuori. — On Tamarix sp. - Endemic.

Tuponia (Tuponia) subaltera Drapolyuk, 1980. - Many exx. from Feyzabad, 16.V.1996; Parvand 70-80 km W of Sabzevar, 14-15.V.1996; Tabas, 16-17.IV.1994. - On Tamarix sp. Known from Middle Asia. New for Iran.

Tuponia (Tuponia) elegans (Jakovlev, 1867). - Many exx. from $15 \mathrm{~km}$ E of Bojnurd, 15.VII. 1994; Darreh Gaz, 15.VI.1994; Feyzabad, 16.V. 1996; Lotfabad, 15.VI.1994; Mashhad, VI-VII. 1994; Parvand 70-80 km W of Sabzevar, 4.VII. 1994; Sabzevar, 29-30.IV.1994; Sarakhs, 29-30. IV.1994; Tabas, 16-17.IV.1994. — On Tamarix sp. - Irano-Turanian. 
Tuponia (Chlorotuponia) prasina (Fieber, 1864). - Several exx. from Darreh Gaz, 15.VI. 1994; Lake Bazangan, 30.VI.1994; Lotfabad, 15.VI.1994; Mashhad, V-VII.1994; Parvand 70$80 \mathrm{~km}$ W of Sabzevar, 4.VII.1994; Sabzevar, 31.V1.VI.1994. - On Tamarix sp. - Pontomediterranean, extending to Middle Asia. New for Iran.

Tuponia (Cholotuponia) kiritshenkoi Drapolyuk, 1982. - Many exx. from Kahe 30-60 km W of Kashmar, 21-22.VI.1994; Sabzevar, 3.VII. 1994; Shams Abad 45 km SE of Kashmar, 2122.VI.1994. - On Tamarix sp. - Known from Middle Asia. New for Iran.

Tuponia (Chlorotuponia) concinna Reuter, 1875. - Numerous exx. from Deh Shor $25 \mathrm{~km} \mathrm{~N}$ of Tabas, 17.IV.1994; Kahe 30-50 km W of Kashmar, 21-22.VI.1994; Parvand 70-80 km W of Sabzevar, 4.VII.1994; Sabzevar, 31.V-1.VI.1994; Tabas, 16-17.IV and 16-18.V.1994. — On Tamarix sp. - Eremian, extending from North Africa to Middle Asia.

Aphaenophyes richteri (Wagner, 1957). Several exx. from Darreh Gaz, 15.VI.1994; Lake Bazangan 50 km W of Sarakhs, 30.VI.1994; Tabas, 16-17.IV and 14-15.V.1994. - On Tamarix sp. - Eremian, extending from North Africa to Iran.

Anonychiella alhagicola alhagicola (Drapolyuk, 1982). - Numerous exx. from Deh Shor 25 km N of Tabas, 16.V.1994; Feyzabad, 16.V.1996; Kashmar, 22-23.V.1994; Lotfabad, 15.VI.1994; Mashhad, VI-VII.1994; Parvand $70-80 \mathrm{~km} \mathrm{~W}$ of Sabzevar, 3.VII.1994; Sabzevar, 3.VII.1994; Tabas, 14-15.IV and 15-18.V.1994. - On Alhagi sp. - Know from Middle Asia. New for Iran.

Anonychiella brevicornis (Reuter, 1879). Sabzevar, 1 ex, 31.V-1.VI.1994. - Irano-Turanian.

Camptotylus meyeri Frey-Gessner, 1863. - Numerous exx. from Sabzevar, 31.V-1.VI and 3.VII.1994; Shams Abad 45 km SE of Kashmar, 23.VI.1994; Tabas, 17.V.1994. — On Tamarix sp. - Caspian. New for Iran.

Camptotylus reuteri Jakovlev, 1881. - Many exx. from Kahe 30-60 km W of Kashmar, 21-22. VI.1994; Sabzevar, 31.V-1.VI.1994. — On Tamarix sp. - Caspian. New for Iran.

Camptotylus gracilis Wagner, 1957. - 2nd antennal segment in Fig. $5 \mathrm{E}$, male genitalia in Figs. 5 F-G and 10 A-E. - $15 \mathrm{~km}$ E of Bojnurd,

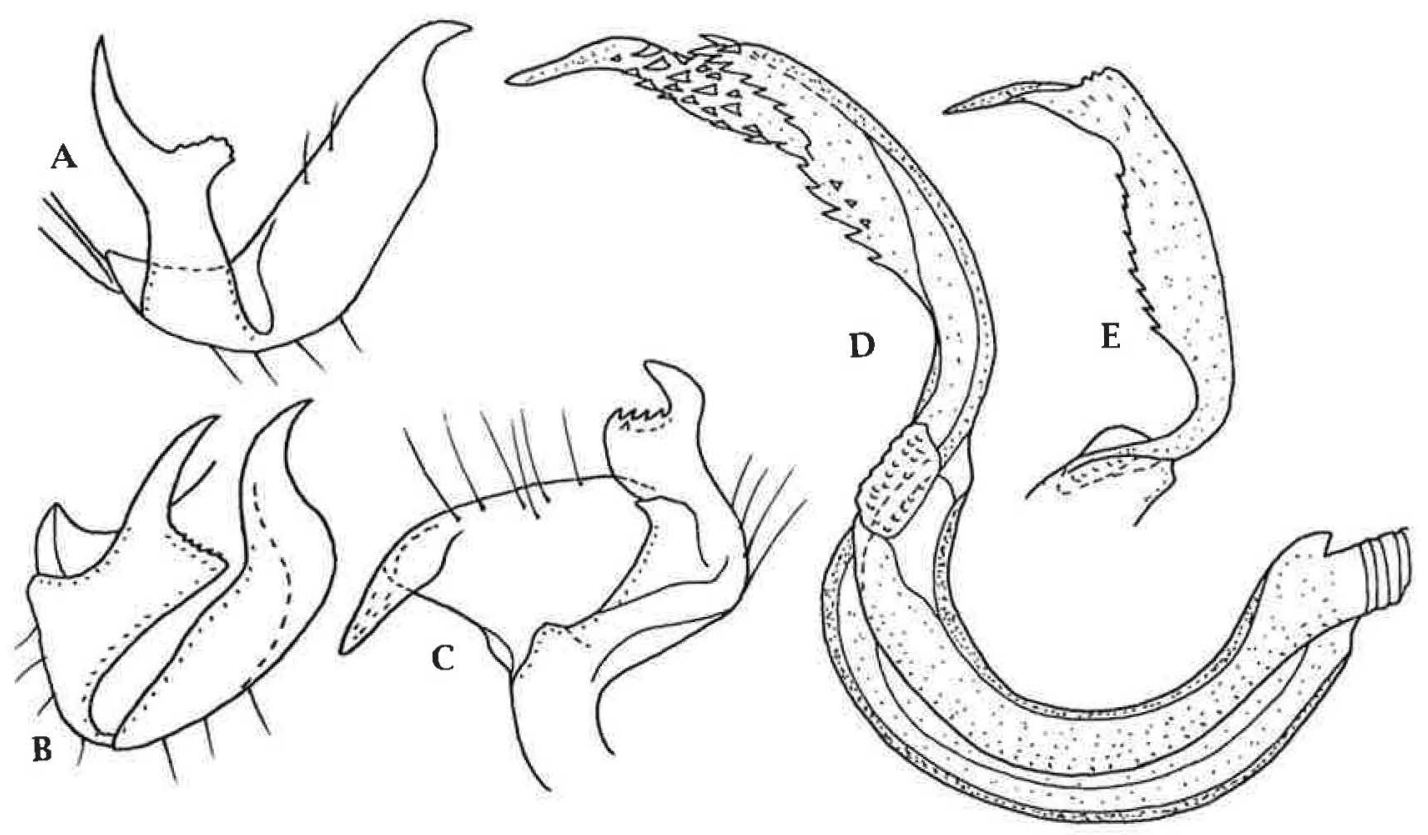

Fig. 10. Camptotylidea gracilis Wagner ( ex from Lake Bazangan): A-C. left style in different views; D. vesica in slide mount; E. apex of vesica in dry mount. 
1 ex, 15.VII.1994; Golmakan Park $150 \mathrm{~km}$ W of Bojnurd, 5 exx., 14.VII.1994; Lake Bazangan, 2 exx., 30.VI.1994. — On Tamarix sp. —-Endemic.

Acknowledgements. The authors are greatly indebted to the Dean, Dr. M.H.Rashed and other members of the Faculty of Agriculture of the Ferdowsi University for all cooperation received during the expedition. We also thank the Finnish Society of Sciences and Letters, Helsinki, for financial help.

\section{References}

Jakovlev, B. E. 1881: Contributions to the fauna of bugs of Russia and the neighboring countries V-VIII. - Bull. Soc. Nat. Moscou 56 (1): 194-214. (In Russian)

Josifov, M. 1974: Eine neue Psallus - Art aus Bulgarien und eine neue Orthotylus-Art aus Kirgisien (Heteroptera-Miridae). - Reichenbachia 15: 89-92.

Kerzhner, I. M. \& Josifov, M. 1999: Miridae. — In Aukema, B.\& Rieger, Chr. (eds.) 1999: Catalogue of the Heteroptera of the Palaearctic Region. Vol. 3. - The Netherlands Entomological Societ, $577 \mathrm{pp}$.

Linnavuori, R. E. 1953: Hemipterological Studies. - Ann. Entomol. Fenn. 19: 109-118.

Linnavuori, R. E. 1975: Hemiptera of the Sudan, with remarks on some species of the adjacent countries. 4. Miridae and Isometopidae. - Ann. Zool. Fenn. 12: 1-118.
Linnavuori, R. E. 1984: New species of Hemiptera Heteroptera from Iraq and the adjacent countries. - Acta Entomol. Fenn. 44: 1-59.

Linnavuori, R. E. 1995: On the Miridae of the Middle East (Heteroptera, Miridae). - Entomol. Fenn. 5: 205-212.

Linnavuori, R. E. 1997a: Taxonomic studies on the Miridae (Heteroptera) of Yemen and Iran. - Acta Univ. Carolinae Biol. 40: 301-320.

Linnavuori, R. E. 1997 b: Taxonomic studies on the Miridae (Heteroptera) of Africa and the Middle East. - Acta Univ. Carolinae Biol. 40: 321-350.

Linnavuori, R. E. 1998: Studies on the Miridae (Heteroptera) of Iran. - Acta Univ. Carolinae Biol. 42: 23-41.

Linnavuori, R. E. \& Modarres, M. 1998: Studies on the Heteroptera of the Khorasan province in N.E. Iran. I. Nepomorpha, Gerromorpha, Leptopodomorpha, Cimicomorpha (Nabidae, Anthocoridae), and Pentatomorpha (Coreoidea), - Entomol. Fenn. 9: 237-241.

Putchkov, V. G. 1975: On the ecology and distribution of certain little known and new species of Miridae (Heteroptera) in Turkmen SSR. — Doklady Akad. Nauk Ukranskoi SSR. Ser. B 8: 753-75. (In Russian)

Putchkov, V. G. \& Putchkov, P. V. 1983: Little known bugs (Heteroptera) of the south of the USSR. - Vest. Zool. 1983 (3): 17-25. (In Russian)

Reuter, O. M. 1890: Capsidae novae e Rossia meridionalis. - Rev. d'Entomol. 9: 246-254.

Wagner, E. 1957: Heteropteren aus Iran 1954 II Teil. Hemiptera- Heteroptera (Fam. Miridae). ( Ergebnisse der Entomologischen Reisen Willi Richter, Stuttgart, in Iran 1954 und 1956. Nr. 9). — Jahrb. Ver. Vaterl. Naturk. Württemberg 112: 74-103. 